\title{
Developing Leaders at Business Schools with Coaching Skills Aligned with the Goals of Responsible Management Education
}

\author{
Dorrian Elizabeth Aiken \\ Cape Town, South Africa
}

\author{
Salome Van Coller-Peter \\ Cape Town, South Africa
}

\begin{abstract}
The invitation for higher education institutions to transform curricula in line with the Principles for Responsible Management Education (PRME) and its 17 Sustainable Development Goals (SDG) sets the background for this paper. In this paper the authors reflect on the viability of providing experiential leadership development in business schools that delivers on the goals of sustainable development, drawing on integral theory and adult development theory. It suggests coaching competencies in particular as an experiential learning approach in the development of leadership ability, with specific focus on self-awareness and ethical relationship management in delivering on SDG.
\end{abstract}

Keywords: experiential learning, leadership development, responsible management education, sustainable development, business schools

\section{Introduction}

In September 2015, the United Nations adopted an agenda that set out a fifteen-year plan "to end extreme poverty, fight inequality and injustice, and protect our planet” (Principles for Responsible Management Education, 2016). The plan includes seventeen Sustainable Development Goals (SDGs) aimed at alleviating the most pressing challenges across the globe, with poverty alleviation, management of resources, economic reform, environmental and ecological sustainability, and ethical leadership being major concerns.

Responsible Management Education (RME) and the Sustainable Development Goals have clearly been linked to the role business schools can play in the development of potential leaders: while a focus on ethical leadership and sustainability has increased in corporations, a recent McKinsey interview reports that the speed and scale of what CEOs need to do is not sufficient (HBR, 2018). In light of RME recommendations, this paper focuses on the 
challenge in a business school context of developing future leaders and CEOs to meet some of the commitments set out in the SDGs.

Developing leadership competencies in those who need to lead in complex environments has been widely noted as challenging (Bennett, 2017; Berger, Hasegawa, Hammerman, and Kegan, 2007; Phillips, Hsieh, Ingene, and Golden, 2016). To be effective leaders in the 21 st century, according to several authors on this topic, business leaders require skills of technical excellence and experience and also the ability to understand and respond positively in relation to the complex range of human experience. They face a business world fast becoming unpredictable - often described as volatile, uncertain, complex and ambiguous. The speed at which change is taking place on several fronts threatens to outpace human capacity to keep up (Friedman, 2016; Kegan, 1994; Kegan and Lahey, 2014; Laloux, 2014; Brown, 2014; Bennet, 2017). In this article, we suggest an approach to developing resilient business leaders through the practical acquisition of coaching competencies. We argue that by the experiential development of practical coaching competencies in potential leaders, business schools can contribute to ethical, resilient leadership that can meet Sustainable Development Goals. This article also addresses the theoretical underpinnings that provide the rationale for skills viewed as critical to such leadership competencies.

\section{Setting the Leadership Development Context}

A case study, an international retail organisation with an enviable reputation for quality and service to its customers, illustrates our theme of developing relational leadership competencies to serve the RME agenda. In 2012, senior executives, who were aware that the organisation in South Africa was not retaining staff, decided upon remedial action: leadership development workshops. Staff members were to give frank feedback to their leaders on their conduct annually. Each year since 2012, in spite of costly leadership development training, staff members' opinions of leadership have become increasingly critical and distrustful, and the retention of good staff continues to be poor. Each year since 2012, leaders have sat down with their teams after the 360-degree feedback to have "an honest conversation" about what needs to change to improve connection between teams and their leaders. Staff members' dissatisfaction with their leaders came to a crisis point towards the end of 2016.

There is no doubt that the organisation's investment in leadership training was genuine and well-intentioned. The problem is that the training happens in a specially created hiatus, suspended outside the daily demands of the normal 
working week. However, after the training, nothing changed. Leaders returned to their teams, under pressure to catch up after their days of off-site training, and their default management and leadership behaviours kicked in. And so the disillusionment, distrust and disengagement of team members eventually increased to a flash point.

The experience described above is not unique in organisations. Petrie (2014) says in this regard:
smart, ambitious managers ... go to leadership development programs. The managers gather in a room, and a trainer teaches those new tools, techniques, and models for how to become a more effective leader. At the end of the program, everyone commits to making big changes back at work. The managers then return to the job and fall into the same old habits they had before the program. What's going on?

It seems, then, that leadership development workshops do not always succeed in achieving effective behavioural change on the job. Business schools are ideally placed to prepare future leaders; however, the question arises in the literature whether business schools are providing the kind of sustainable leadership and management skills that translate into positive impact on employees, let alone whether they achieve the global Sustainable Development Goals. Business schools have been criticised by some, especially since the financial crisis of 2008, for their dedication to business management theory where students are encouraged to adopt an attitude of self-interest and material enrichment (Giacalone \& Thompson, 2006, p. 267). Canals (2009) expresses the opinion that management models lack any sense of human presence. In her study of business schools in South Africa, the UK and the USA, Saunders (2011) comments that while there has been an increasing focus over the last decade on leadership and team-building skills within organisations, business schools have lagged behind in introducing team-building and leadership skills as theory or practice into the curriculum.

Is it fair to say that business schools neglect the human element? We find this critique somewhat harsh and certainly not entirely true of the content we facilitate at our own business school. MBA students are increasingly incorporating leadership theory into their programmes. However, the problem word here is theory. Wonderful tomes on leadership give insight into the importance of establishing positive relationships and ethical values-based interactions (Veldsman \& Johnson, 2016). Students engage individually or in cohorts to research and discuss their findings on leadership for the preparation of assignments and presentations. The issue is that, in the main and with few 
exceptions, the learning remains fragmented and at a cognitive level. Neuroscience research has found that acquiring sustainable new behaviours, such as would support values-based innovative leadership, is primarily a limbic brain function. As such it requires learning stimulated by experiential insight into self and continuous practice with others (see for example Sapolsky, 2017; Doidge, 2007, 2012; Lipton, 2008; Merzenic, 2014; Barrett, 2017). Although intended to be both challenging and supportive, even engagement in small groups is likely an exchange of views and information at the cognitive level. The degree of experiential and self-reflective learning, and the regular practising that is required by leaders to master sustained and skilful leadership behaviours, seems to be notably absent from mainstream MBA studies. As Muff (2013) maintains, textbook learning cannot serve as a substitute for ongoing practical experience.

The achievement of these leadership competencies depends upon an ongoing process of self-development, a life-style practice - not likely the outcome, as our case example at the start of this section illustrates, of a threeday or even ten-day leadership development programme. As Petrie (2014) has commented, leadership development should be an ongoing process, "not an event." Thus, in increasingly volatile and unpredictable environments, we argue that leadership is a basket of skills that would benefit from the inclusion of coaching competencies, requiring daily practice on the job - a practice that should (and in some places, already does) begin at business school. To return to the above-mentioned case study, leaders in the troubled organisation cognitively understood the connection between the quality and consistency of positive engagement with their teams and their performance. However, the translation of this cognitive knowledge into daily practice of behaviours on the job with their teams has not yet become a non-negotiable requirement. In support of the RME agenda, business schools have the opportunity to integrate coaching practices as a non-negotiable part of leadership behaviours along with technical business skills in order to meet volatile, unpredictable relationship challenges.

\section{A Coaching Approach For Leadership Development}

In University of Stellenbosch Business School's MPhil in Management Coaching programme we aim to develop leaders and managers who are competent coaches, in the belief that the requisite skills of a good coach grow more awareness of complexity and ambiguity and consequently build more resilience in leaders. A core focus of the programme is how the students discover subjectivity, or the ways in which their views of reality have been constructed - what they have chosen to believe and the lenses through which 
they have interpreted and engaged with the world. Construct development theorists like Robert Kegan (2016), Susan Cook Greuter (2005), Bill Torbert (2004) and Barrett Brown (2012) have provided frameworks that illustrate constructs at the different stages of adult development, from limited complexity and perspective-taking to multiple ways of seeing and engaging with the world.

\section{Vertical Learning}

We conjecture, based on evidence issuing from the work of Susanne Cook Greuter (2005) and her Leadership Maturity Framework, as well as the MetaIntegral Institute, to name just two examples, that business schools can create environments that are conducive to growing awareness in potential business leaders of more complexity and perspective-taking than they may currently be aware of, particularly at an emotional and interpersonal level. Such increased conscious awareness, the process of vertical learning, may enable leaders to inspire teams and find solutions to some of the world's most pressing challenges as set out in the Principles of Responsible Management Engagement.

Both horizontal (translational) learning and vertical (transformational) learning are important in leadership development (Petrie, 2014). In this context, horizontal learning refers to the process of increasing knowledge and competencies - what leaders should know and do. It is primarily a function of cognitive (neocortical brain) intelligence. Vertical growth refers to an increase in a person's ability to think in increasingly complex ways, to be comfortable with multiple perspectives and to connect meaningfully across differences. Holding such complexity with ease is a function of emotional and interpersonal intelligence, more likely part of coaching training than conventional leadership development with its emphasis on developing cognitive intelligence. In a white paper entitled The Future of Leadership for Conscious Capitalism (MetaIntegral Associates, 2014), Barrett Brown claims that vertical learning is a natural stage-development process, but that it can be accelerated significantly under the right conditions. He notes that, by and large, leadership development is a horizontal learning process in conventional, tradition-based programmes, yet leading centres at Harvard, Stanford and Cambridge place vertical learning at the core of their prestigious leadership development programmes.

Furthermore, he cites the Centre for Creative Leadership as naming vertical learning the number one future trend in leadership development.

As Laloux (2014) demonstrates in his research on organisations, when individuals are surrounded by colleagues who hold more complex views of the 
world, and they feel safe enough to reflect on conflicting points of view, there is a strong likelihood of a shift to embracing multiple perspectives. These capabilities suggest themselves as appropriate to meet the challenges of the SDGs. Laloux also shows that when employees are managed by leaders who see and engage with them in more complex ways, and whose behaviours are respectful and inclusive of all levels of staff, overall performance improves. However, leaders in these organisations first need to know how to include and elevate others to the required level of thinking and operating. Indeed, the model or framework suggested for the focus and implementation of SDGs emphasises, among six other imperatives, top-down commitment from leadership and bottom-up commitment from faculty and staff. We conjecture that leaders with a skilful coaching style stand a greater chance of success in engaging positive commitment from employees because of the fundamental principles of coaching: listening attentively, building trust, encouraging potential, and ensuring accountability.

\section{The process of developing leaders with a coaching style}

A long part of the journey to becoming a coach is to be comfortable with accepting who we are, what we think and how we behave. Undoubtedly, the skill that facilitates the most transformation during the process of becoming a coach is that of reflective practice. As part of the MPhil in Management Coaching, students' reflective practices are built up from a simple model like Borton's (1970) to the more intricate model of Kimber (2003). Borton's model asks three simple questions: What came up for you during a learning activity that caused an 'aha' moment? The next questions ask: So what? How is it significant for you? What did it trigger within you that is worth exploring on your learning journey? The third questions ask: Now what? How can you capitalise on the new insight to further your thinking and practice so as to enhance your competence in providing a richer coaching experience for both your client and yourself?

A step-up in complexity from Borton's model, Kimber's model encourages reflection on three different levels, leading from surface evidential data or Level 1 content to Level 2 (what process is used to unpack the content) and Level 3 (what premise underpins and informs the content and process). Thus, insight is deepened by developing awareness of our own processes of learning and thinking, as well as becoming intrigued by the sense-making of others. Becoming aware of constructs and meaning-making is significant for coach training if leaders are to help others recognise not only their own constructs, but also the possibility for multiple ways of making meaning. 


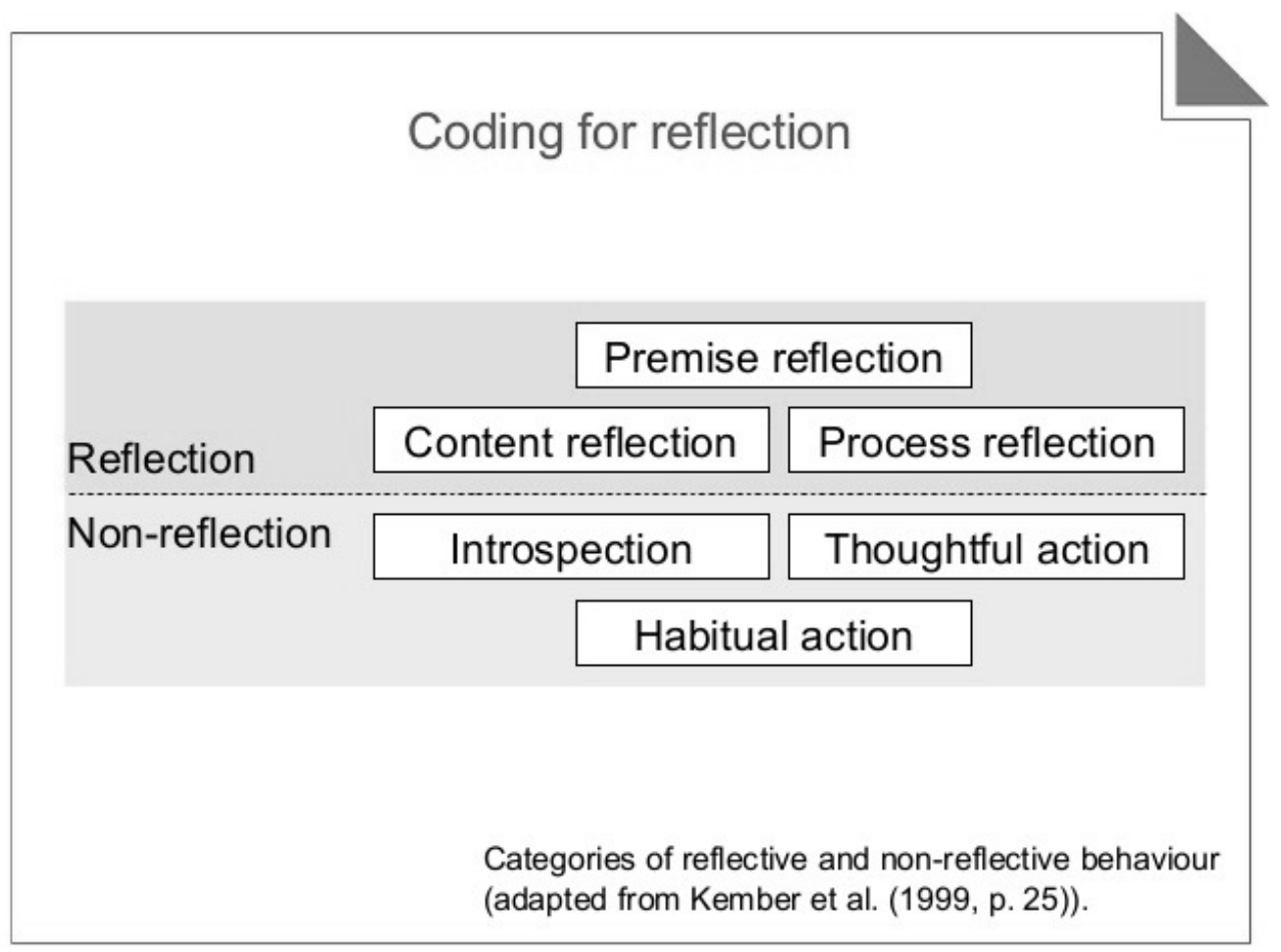

Figure 1: Analysing reflections

Good coaching skills focus on how leaders consistently engage with stakeholders, colleagues and staff, along with the technical competencies of what they are expected to achieve. Good coach training translates leadership development theory into positive engagement. We have already described the practice of self-reflection. Neuroscience emphatically confirms that sustained behaviour change takes place only with iterations of practice, with practical experiences that challenge beliefs, values, emotions and habits (Doidge, 2007; Lipton, 2008; Merzenich, 2013; Lewis, Amini, and Lannon, 2001). As stated earlier in this article, reading a book, no matter how brilliant, is unlikely to bring about sustained behaviour change. The many leadership and self-help books that abound are testimony to the impotence of cognitive intelligence (a neo-cortical brain function) to influence emotional and interpersonal intelligence (a limbic brain function) in the absence of direct experience (Lewis et al, 2001, p. 118). Neuroplasticity, the ability for new neural pathways to develop in the brain in response to sustainable new learning, is possible for everyone - the caveat is that it requires practice. What follows are some of the other critical skills for developing leaders with a coaching style. 


\section{Critical skills for ethical leadership with a coaching style}

Leaders require particular skills to function optimally in a volatile, fastchanging world. Here we focus on the art of listening, building trust, and engaging the power of the limbic brain.

\section{The art of listening}

Kevin Sharer (2012), the CEO of Amgen, says of the art of listening:

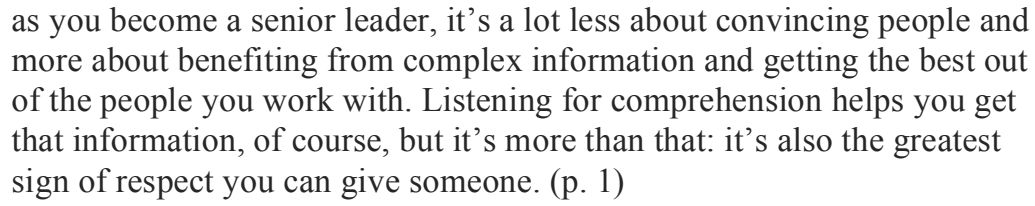

The practice of truly listening without allowing the intrusion of one's own thoughts and without interruption or asking leading questions is a powerful discipline in developing vertical altitude. It requires more mature egos: such leaders are less prone to knee-jerk reactions or acting on split-second judgements, and more capable of impulse control (Charan, 2012). Apart from the benefits for the listener in maturing leadership ego, the benefits for the thinker are numerous: the positive impact of being heard, of having uninterrupted time to think and, as a consequence, feeling valued as an employee, team member or colleague (Zak, 2017). Google's two-year search for the ideal team conditions (Duhigg, 2016) led to the discovery that, quite simply, the building blocks were being heard, feeling valued and thereby creating trust. However, it is a journey from discovering the right leadership ingredients to the leader being able to bake the perfect team cake.

Our students in the MPhil in Management Coaching programme begin with three-minute practice sessions, in pairs, giving perfect attention to a fellow student. At the first few attempts of simply allowing someone to do his or her own free thinking for just three minutes, without interruption or asking questions generated by their own curiosity, the listeners were asked how difficult it was to give this kind of attention unconditionally. With ongoing practice during the course of the year, the emotional and interpersonal maturity of the listeners increased significantly. This advance in their development became visible in the quality of their attention to the thinker, and in being able to hold silence and create the conditions to keep the thinker deeply engaged with the topic. The impact on the thinker, when the listening is this good, is 
unfailing appreciation for the depth and richness of the experience (Kline, 1999) .

Trust and the power of the limbic brain

Zak (2017) says the following about trust:

Leaders understand the stakes - at least in principle. In its 2016 global CEO survey, $\mathrm{PwC}$ reported that $55 \%$ of CEOs think that a lack of trust is a threat to their organization's growth. But most have done little to increase trust, mainly because they aren't sure where to start.

Students in our Masters in Management Coaching programme are introduced to David Rock's SCARF (Rock 2008), an effective, accessible model which describes five key triggers to the limbic brain. The students are able to engage emotionally with the positive and negative impact of these five triggers - status, certainty, autonomy, relatedness and fairness - drawing on their own experiences. Research provides the evidence that emotionally intelligent leaders build trust, engender loyalty, and enhance motivation when they consciously affirm status, give certainty and autonomy and assure fairness (Ringleb, Rock \& Ancona 2012). The ability to build positive relationships with SCARF in mind is an important component of learning to lead effectively by making use of coaching competencies (Rock, 2006).

\section{Conclusion And Recommendations}

This article focused on developing coaching skills that emphasise reflective awareness in current and future leaders studying at business schools. Our belief, based on our own experience at University of Stellenbosch Business School, is that business schools can play a powerful role in accelerating vertical learning by training potential business leaders to use coaching skills to create more resilient business environments. We conclude this opinion piece with these questions for business schools (developed by Saunders (2011), drawing on the unpublished dissertation of Coetzee (2009)):

- What future does humankind want?

- What kind of society will create this future?

- What kind of business does this type of society require?

- What kind of leader does this kind of business need?

- What kind of MBA does this kind of business leader need? 
Based on this set of questions and the discussion in this article, we draw the following conclusions about the mindsets that professional ethical leaders need, and the experiential practices that business schools need to instil in order to fulfil the RME agenda by 2030. In considering the theory and practices and in particular the concept of vertical learning, we suggest that leadership ability to implement the RME goals in the next ten to fifteen years be facilitated by the inclusion of coaching skills at business schools that aim to increase developmental consciousness and complexity in future leaders by experiential learning. Such leaders in the workplace would then continue to raise the standard of trustworthy, innovative and resilient leadership in the pursuit of achieving the Sustainable Development Goals so critical to the improved wellbeing of all.

\section{References}

Barrett, Lisa Feldman. (2017). How emotions are made: The secret life of the brain. UK: Macmillan

Bennett, K. (2017). Living and Leading Through Uncertainty: Developing leaders' capability for uncertainty. Sandton: Knowledge Resources.

Berger, J.G., Hasegawa, B., Hammerman, J. and Kegan, R. (2007). How Consciousness Develops Adequate Complexity to Deal With a Complex World: The Subject-Object Theory of Robert Kegan. Available online: http://terrypatten.typepad.com/iran/files/keganenglish.pdf [Accessed: 17 January 2017].

Brown, B.C. (2014). The Future of Leadership for Conscious Capitalism. MetaIntegral Associates.

Brown, B.C. (2012). Conscious leadership for sustainability: How leaders with a late-stage action logic design and engage in sustainability initiatives. Doctoral dissertation. California: Fielding Graduate University.

Cacioppe, R. and Edwards, M. (2005). Seeking the Holy Grail of organisational development: A synthesis of integral theory, spiral dynamics, corporate transformation and action inquiry. Leadership \& Organization Development Journal, 26(2), 86-105. http://dx.doi.org/10.1108/01437730510582536.

Canals, J. (2009). Seeking a greater impact: New challenges for business schools. Retrieved from http://www.iese.edu/research/pdfs/DI-0838E.pdf

Charan, R. (2012, June). The Discipline of Listening. Harvard Business Review. Retrieved from https://hbr.org/2012/06/the-discipline-oflistening 
Cook-Greuter, S. (2005). Ego Development: Nine Levels of Increasing Embrace. Retrieved from: http://areas.fba.ul.pt/jpeneda/CookGreuter.pdf [Accessed: 27 January 2017].

Doidge, N. (2007). The Brain that Changes Itself. New York: Penguin. Doidge, N. (2015). The Brain's Way of Healing. New York: Viking.

Duhigg, C. (2016, Feb). What Google Learned from its Quest to Build a Perfect Team. New York Times Magazine. Retrieved from https://www.nytimes.com/2016/02/28/magazine/what-google-learnedfrom-its-quest-to-build-the-perfect-team.html

Friedman, T. (2016) Thank you for being late: An optimist's guide for thriving in an age of acceleration. New York: Farrar Straus and Giroux

Gentile, M. (2014). The Holy Grail: Educating for values-driven leadership across the curriculum and giving voice to values. EFMD Global Focus, $8(1)$.

Giacalone, R.A. and Thompson, K.R. (2006). Business ethics and social responsibility education: Shifting the worldview. Academy of Management Learning \& Education, 5(3), 266-277. Doi: 10.5465.AMLE.2006.22697016.

HBR, 2018. McKinsey's Head on Why Sustainability Efforts Are Falling Short. Harvard Business Review Ideacast. Retrieved from https://hbr.org/ideacast/2018/03/mckinseys-head-on-why-corporatesustainability-efforts-are-falling-short

Kegan, R. and Lahey, L. (2016). An Everyone Culture: Becoming a deliberately developmental organisation. Brighton, Massachusetts: Harvard Business Review Press.

Kegan, R. (1994). In Over Our Heads: The mental demands of modern life. Brighton, Massachusetts: Harvard Business Review Press.

Kegan, R. (1982). The evolving self: Problem and process in human development. Cambridge, MA: Harvard University Press.

Kline N. (1999). Time To Think: Listening to Ignite the Human Mind. UK: Wardlock

Koljatic, M. and Silva, M. (2015). Do Business Schools Influence Students' Awareness of Social Issues? Evidence from Two of Chile's Leading MBA Programs. Journal of Business Ethics, 131(3), 595-604. DOI 10.1007/s10551-014-2295-4.

Laloux, F. (2014). Reinventing Organizations: A guide to creating organizations inspired by the next stage of human consciousness. Millis, MA: Nelson Parker.

Lewis T, Amini F, Lannon R. (2001). A General Theory of Love. New York: Vintage 
Lipton, B. (2008). The Biology of Belief. Unleashing the Power of Consciousness, Matter \& Miracles. California: Hay House Inc.

Merzenich, M. (2013). Soft-wired: How the new science of brain plasticity can change your life. San Francisco, California: Parnassus Publishing.

Mitroff, I. (2004). An open letter to the deans and faculties of American business schools. Journal of Business Ethics, 54, 185-189.

Muff, K. (2013). Developing globally responsible leaders in business schools: A vision and transformational practice for the journey ahead. Journal of Management Development, 32(5), 487-507. Doi: $10.1108 / 02621711311328273$.

Petrie, N. (2014). Vertical Leadership Development - Part 1. Developing Leaders for a Complex World. Center for Creative Leadership. Retrieved from http://www.nicholaspetrie.com/vertical-leadershipdevelopment [Accessed: 17 January 2017].

Phillips, F., Hsieh, C.H., Ingene, C. and Golden, L. (2016). Business schools in Crisis. Journal of Open Innovation, 2(10). Doi:10.1186/s40852-0160037-9.

Ringleb, A. \& Rock, D. (2008). The emerging field of neuroleadership. NeuroLeadership Journal, (1), 3-19.

Ringleb, A., Rock, D., \& Ancona, C. (2012). Neuroleadership in 2011 \& 2012. NeuroLeadership Journal, (4), 1-34

Rock D. (2006). A Brain-based Approach to Coaching. International Journal of Coaching in Organisations, 4(2), 32-43.

Rock, D. (2008). SCARF: A brain-based model for collaborating with and influencing others. NeuroLeadership Journal, (1). Retrieved from https://www.epa.gov/sites/production/files/201509/documents/thurs_georgia_9_10_915_covello.pdf

Sapolosky, Robert. (2017). Behave: The biology of humans at our best and worst. UK: Bodley Head.

Scharmer, O. and Kaeufer, K. (2013). Leading from the Emerging Future. San Francisco, CA: Berrett-Koehler.

Sharer K. (2012, April). Why I'm a Listener. McKinsey Quarterly. Retrieved from https://www.mckinsey.com/featured-insights/leadership/why-im-alistener-amgen-ceo-kevin-sharer

Principles for Responsible Management Education: An Initiative by the United Nations Global Compact. (2016). Transformational Model for Prime Implementation. Retrieved from http://www.unprme.org/resourcedocs/PRMETransformationalWeb.pdf

Veldsman, T. H. and Johnson, A. J. (Eds). (2016). Leadership. Perspectives from the Front Line. Randburg: KR Publishing. 
Torbert, W. (2004). Action Inquiry: The secret of timely and transforming leadership. San Francisco, CA: Berrett-Koehler.

Whiting, J., Jones, E., Rock, D. and Bendit, X. (2013). Lead Change with Brain in Mind. NeuroLeadership Journal, (4). Retrieved from

http://implementconsultinggroup.com/media/2949/lead-change-withthe-brain-in-mind.pdf

Zak, P. (2017, Jan-Feb). The Neuroscience of Trust. Harvard Business Review. Retrieved from https://hbr.org/2017/01/the-neuroscience-of-trust 